\title{
Belgeo
}

Revue belge de géographie

4 | 2018

Transformations of urban space after the fall of Socialism

\section{Impacts of urbanization on green infrastructure ecosystem services: the case study of post-soviet Moscow}

Oxana Klimanova, Eugeny Kolbowsky and Olga Illarionova

\section{CpenEdition}

\section{Journals}

Electronic version

URL: http://journals.openedition.org/belgeo/30889

DOI: 10.4000/belgeo.30889

ISSN: 2294-9135

Publisher:

National Committee of Geography of Belgium, Société Royale Belge de Géographie

Electronic reference

Oxana Klimanova, Eugeny Kolbowsky and Olga Illarionova, «Impacts of urbanization on green infrastructure ecosystem services: the case study of post-soviet Moscow », Belgeo [Online], 4 | 2018, Online since 09 January 2019, connection on 09 October 2020. URL : http://journals.openedition.org/ belgeo/30889; DOI : https://doi.org/10.4000/belgeo.30889

This text was automatically generated on 9 October 2020 .

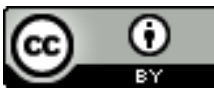

Belgeo est mis à disposition selon les termes de la licence Creative Commons Attribution 4.0 International. 


\title{
Impacts of urbanization on green infrastructure ecosystem services: the case study of post-soviet Moscow
}

\author{
Oxana Klimanova, Eugeny Kolbowsky and Olga Illarionova
}

\section{Introduction}

1 The ecosystem services (ES) are defined as the benefits humans draw from the functioning and processes of ecological systems (Costanza et al., 1997; Daily et al., 1997; De Groot et al., 2002). According to The Millenium Ecosystems Assessment Report (2005), ES are divided into four groups: supporting, provisioning, regulating and cultural.

2 The continuous increase in the number and size of cities and the ensuing transformation of virgin landscapes on different scales pose significant challenges for reducing the rate of biodiversity loss and related ecosystem functionality and ensuring human welfare (Haase et al., 2014). However, urban areas also provide a range of benefits to sustain and improve human livelihood and the quality of life through urban ecosystem services (UES) (TEEB, 2011), generated by green infrastructure.

The analytical construct of UES seems to be a more pragmatic strategy to ensure that the impacts of urbanization, climate change and socio-ecological transformations on the urban environment are addressed (Atif, 2018).

4 A spatial analysis of urban GI is an important starting point for assessing UES. The elements of GI in the urban area represent habitats for numerous species and provide a high variety of ecosystem services (Grunewald, 2018). European spatial planning practice define green infrastructure (GI) as "a strategically planned network of natural and semi-natural areas with other environmental features designed and managed to deliver a wide range of ecosystem services" (European Commission, 2013). 
5 Recent literature indicates that examples of most important UES include: air pollution and stormwater runoff reduction (Baró et al., 2014; Inkilainen et al., 2013), building energy savings from reduced heating and cooling costs, and the associated avoided carbon emissions from reduced energy use (Akbari, 2002; Sawka et al., 2013) and carbon dioxide sequestration (Nowak et al., 2013).

6 From the point of GI view, the urbanization means transformation of semi-natural and natural ecosystems in urban and peri-urban areas by impervious surfaces. That leads to the ecosystems' loss and decreasing the provision by UES. The problem has been addressed in many previous studies. Eigenbrod et al. (2011) research revealed a correlation between urban expansion and decrease in carbon storage capacity and timber volume in Great Britain. Works on urban ES in Chinese cities (Xie W. et al., 2018; Zhang D. et al., 2017) reveal negative influence of urban area growth on air quality, food production, soil conservation and water purification. As De Carvalho R. M (2018) shows that loss of urban ES also affects cities' adaptation to climate change. It was determined that densely built-up and scarcely vegetated areas are more vulnerable to climate change than suburban (more sparsely built-up) ones (Andre, Zuvela-Aloise et al., 2017). Areas in poor ecosystem condition (i.e. degraded ecosystems) may hinder the longterm provision of multiple ES (Benayas et al., 2009; Frélichová, Fanta, 2015). Moreover, the fragmentation of green massifs and breaks in green corridors decrease biodiversity and hamper animals' migration (Irwin, Bockstael, 2007).

7 Urban planning aims to curb the cities' sprawl and reach balance between built-up and unsealed areas. When analyzing urbanization in Europe, urban planning of Russian cities is usually neglected. They, however, represent a unique form of European cities, as well as having the largest population out of all cities of other post-soviet countries.

8 Urban green space as a resource of urban nature was largely underestimated in most of the socialist countries. Thus, it was also underdeveloped as a prospect of healthy and liveable environments (Ignatieva et al., 2013), despite the proclamation of the importance of green spaces, for example, in the Soviet Union. In the phase of postsocialist transformation, new priorities, such as economic restructuring, dwarfed the debate on urban nature and greening (Haase et al., 2014). At this context the urbanization experience of Post-Socialist countries is quite unique. Most of these countries attained high-urbanization levels under a centrally-planned system, in which non-economic factors were pivotal in shaping the spatial distribution of both the population and economic activities.

9 The aim of this article is to define the role of urban expansion in changing ecosystem's services of green infrastructure ${ }^{1}$ in different parts of Moscow during the last 25 years that were the period of post-soviet development of the Russian capital.

10 Moscow urban area is unique due to both its size and economic value on the national level (Mahrova, Nefedova \& Treivish, 2012). It is the most populated city not only in Russia, but in Europe as well. In post-socialist period between 1991 and 2016, city population increased from 9.02 to 12.3 billion people and it continues to grow. During the last 25 years since the USSR collapse, Russian economy has been enduring some serious transformations that have only increased Moscow's significance. At the same time, strong restructuring in urban economy took place which lead to a non-industrial sector's growth and industrial production decrease. 
11 The development of GI in Moscow is profusely funded by the government, setting an example of urban environmental management for other cities. Despite these improvements within Moscow, rural landscapes are still being transformed, meaning the whole urban area provides less ES.

12 The city both inherits features of central planning and integrates modern methods of greening. Thus, case study of Moscow presents an interesting example of post-Soviet transformation of GI.

\section{Methods}

\section{Study area}

First significant development of GI in Soviet Moscow took place when implementing the Master Plan of 1935. It resulted in (i) the protection and management of a Green Belt around the city, (ii) the establishment of seven major green zones stretching from outskirts to the center and (iii) a connecting system of boulevards and parks. With urban planning standards for residential areas aiming at $14 \mathrm{~m}^{2}$ of green area per capita (Baranov, 1969), Moscow could be considered a city with a well-developed GI.

During the Soviet period, the concept of urban GI - mostly addressed as "ecological network" (Vladimirov, 1980, 1982) - lied in the GI availability and even distribution. Requirements for green area per capita depended on climate zones and cities' population while numerous planting standards included the share of green area in residential areas ( $40 \%$ at least), the number and size of green elements per district, etc. Master Plans for large cities often incorporated green networks that connected vegetated areas and water bodies of different sizes, fitting into the urban pattern. As a result, a lot of post-Soviet cities like Moscow, Tartu, Yerevan and Minsk still retain traces of former Green Belts. However, continuous reorganization of urban planning, standards and policy alterations led to significant transformation of all green elements, with Moscow GI being a fine example of this process (Voroncov, 2016).

During the first post-Soviet decade, green zones were generally neglected due to the economically stipulated reasons and weak environmental policy. Combined with population growth and subsequent development of building sector, Moscow GI was severely depleted. It wasn't until the heatwave and smog in Moscow in 2010 that GI ecosystem regulating and mitigating services were acknowledged. Today, the term "ecosystem services" is still to be used in the largest cities' Master Plans. Its concept, though, is not completely absent as the strategic documents often mention recreational and regulating GI functions. The latest Master Plan of Moscow for the period of 2017-2035, while not introducing the term, addresses five GI ecosystem services, including noise reduction, biodiversity conservation, climate regulation, erosion control and recreation.

Due to the administrative reform in 2012, the area of Moscow became twice its size. (Figure 1). Unlike before, when the city's administrative borders were - more or less equally - enlarged in all directions, the latest expansion took place exclusively and very widely towards the south-west. Since it was open lands and forest that were mostly adjusted to the original city's area (Kolbowsky et al., 2015, 2013), a special plan to prevent their destruction has been developed. Its aim was to implement special 
regimes to natural areas and cultural landscapes according to their regulating and recreational ES and particular management and maintenance requirements.

Figure 1. Study area - Old and New Moscow.

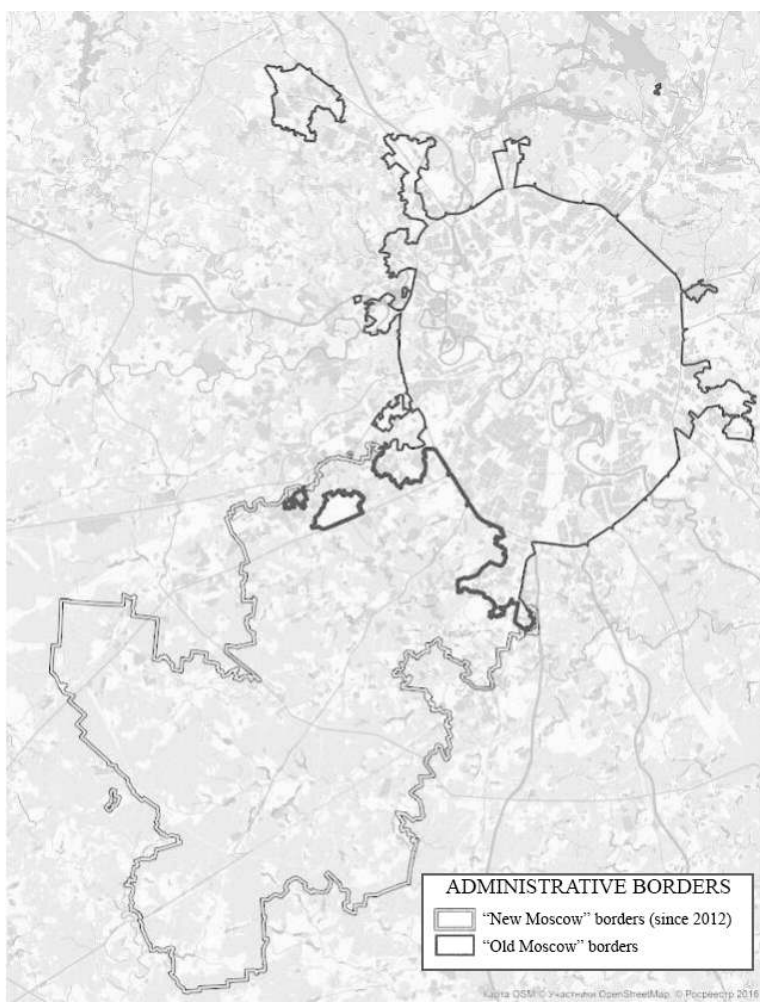

\section{Methodology}

Data on GI area and elements was received by analyzing geo-data from open sources. Urban Atlas does not have GI classification for Moscow like for other 300 European cities, hence we developed a similar map by using vectors from Open Street Map. We chose layers, containing information on land-use, vegetation, surface and POI (Points of Interest) and reclassified them with accordance to Urban Atlas codes. To assess UES, we used the classification of Green Infrastructure and Territorial Cohesion (EEA, 2011), based on the spatial data of the Urban Atlas.

To get data on spatial distribution of urban sprawl processes, we used Atlas of Urban Expansion (1991-2015). For the Atlas composition cloud free images from Landsat 5 (1984), Landsat 6 (1993), Landsat 7 (1999) and Landsat 8 (2013) satellites ${ }^{2}$ were used. The data was reclassified by 7 types of urban tissue: 1) urban built-up, 2) suburban built-up, 3) rural built-up, 4) fringe open space, 5) captured open space, 6) rural open space and 7) water. These types of urban patterns were defined depending on the majority of built-up pixels (50\% or more) (for types 1-3) and the belt around built-up pixels up to 100 meters (for types 4-6). Then we calculated how much the area of every land-use type has changed during 1990-2015.

After obtaining data on urban land types, we compared them with types in Atlas of Urban Expansion (Table 1). The transformation of GI ecosystem services was calculated on the base of reclassified in ArcMap 10.5 urban land types. 


\section{Results}

\section{Spatial distribution of green infrastructure elements and ecosystem services}

Configuration and composition of GI in so-called "Old" and "New" Moscow are quite different. "Old Moscow" historically has a radial planning structure. Urban protected green zones, situated on the periphery of "Old Moscow", are mostly presented by parvifoliate, broadleaf and mixed (including pine woods) forests, wetlands and meadows. Before the joining, "New Moscow" was a thinly populated area $(250,000$ people) with a high percentage of agricultural lands in its land use structure. More than $50 \%$ of the forested area is presented by parvifoliate species, dominated by aspens and birches (almost $65 \%$ of all forest). Coniferous trees, planted in the 20th century, occupy about one quarter of the forest area. Finally, broadleaf forests, mostly presented by oak, cover a relatively small area (less than $6 \%$ of all forested lands). There are barely any protected green zones within "New Moscow" limits, although forests between "Old" and "New" Moscow that make up a city's green buffer are under a special governmental protection.

21 An integration of open data from Open Street Map and a composition of its classification with Urban Atlas codes enabled us to create a land-use maps of "Old" and "New" Moscow (Figure $2 \mathrm{a}, \mathrm{b}$ ) that was consequently used to esteem ecosystem services (Table 1).

Figure 2a. Land use types in "Old" Moscow.

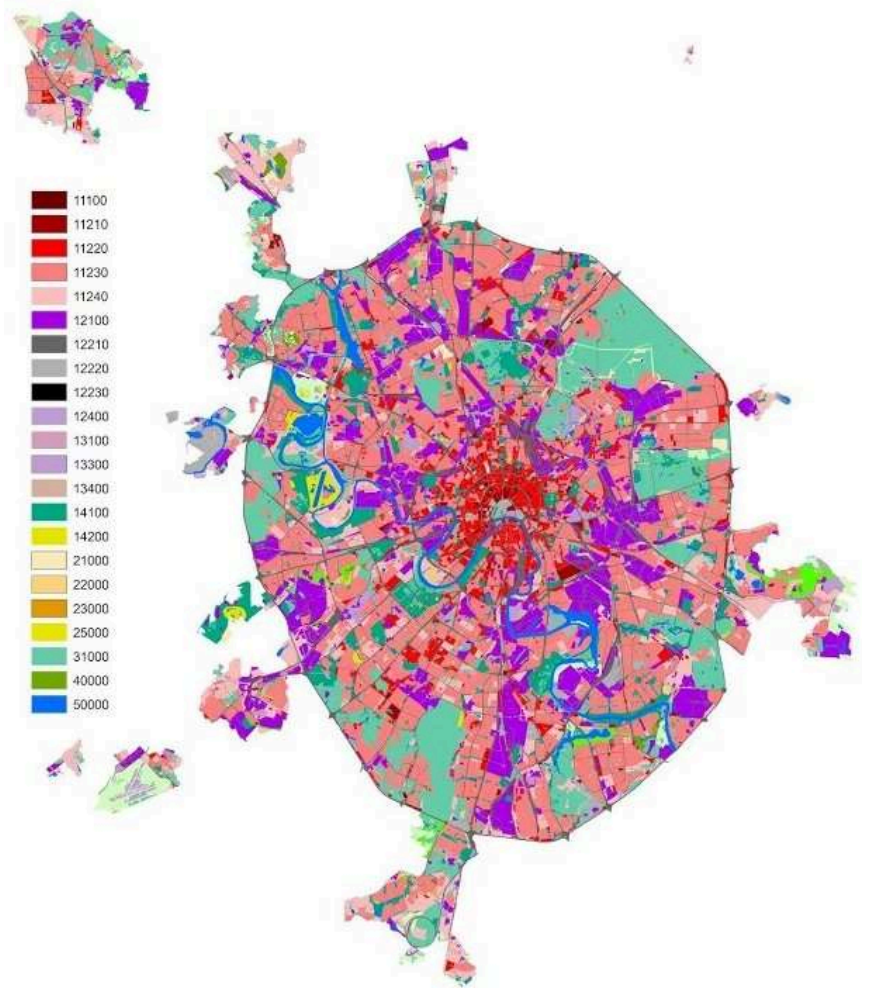

Indexes of land use types codes correspond to Urban Atlas Codes (Urban Atlas Mapping Guide, 2011) and are explained in Table 1. 
Figure 2b. Land use types in "New" Moscow.

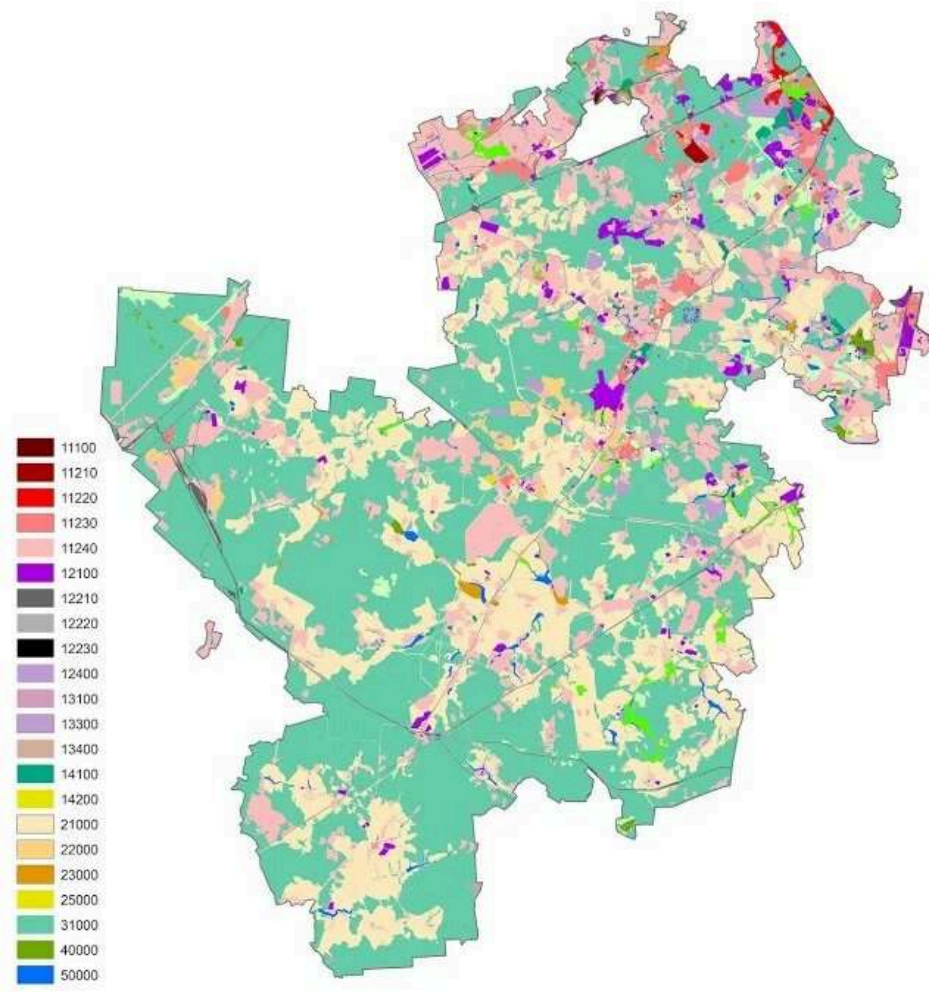

Table 1. Urban Atlas codes in Moscow (2015).

\begin{tabular}{|c|c|c|c|c|c|c|c|}
\hline \multirow{2}{*}{$\begin{array}{l}\text { Urban Atlas } \\
\text { Code }\end{array}$} & \multirow[t]{2}{*}{ ITEM } & \multicolumn{2}{|c|}{ Old Moscow } & \multicolumn{2}{|c|}{ New Moscow } & \multicolumn{2}{|c|}{ Big Moscow } \\
\hline & & Area (ha) & Area (\%) & Area (ha) & Area (\%) & Area (ha) & Area (\%) \\
\hline 11100 & Continuous urban fabric (S.L. > 80\%) & & 0,06 & 25 & 0,02 & 85 & 0,03 \\
\hline 11210 & $\begin{array}{l}\text { Discontinuous dense urban fabric (S.L. } \\
50 \%-80 \%)\end{array}$ & 1189 & 1,09 & 111 & 0,08 & 1300 & 0,51 \\
\hline 11220 & $\begin{array}{l}\text { Discontinuous medium density urban } \\
\text { fabric (S.L. } 30 \%-50 \%)\end{array}$ & 5107 & 4,68 & 345 & 0,24 & 5452 & 2,12 \\
\hline 11230 & $\begin{array}{l}\text { Discontinuous low density urban fabric } \\
\text { (S.L. 10\%-30\%) }\end{array}$ & 31493 & 28,88 & 2849 & 1,97 & 34343 & 13,38 \\
\hline 11240 & $\begin{array}{l}\text { Discontinuous very low density urban } \\
\text { fabric (S.L. }<10 \%)\end{array}$ & 9911 & 9,09 & 24155 & 16,69 & 34499 & 13,44 \\
\hline 12100 & $\begin{array}{l}\text { Industrial, commercial, public, military } \\
\text { and private units }\end{array}$ & 13533 & 12,41 & 2550 & 1,76 & 16090 & 6,27 \\
\hline 12210 & Fast transit roads and associated land & 6757 & 6,20 & 961 & 0,66 & 7772 & 3,03 \\
\hline 12220 & Other roads and associated land & 5873 & 5,39 & 2861 & 1,98 & 8831 & 3,44 \\
\hline 12230 & Railways and associated land & 2733 & 2,51 & 679 & 0,47 & 3412 & 1,33 \\
\hline 12400 & Airports & 179 & 0,16 & 0 & 0 & 179 & 0,07 \\
\hline 13100 & Mineral extraction and dump sites & 34 & 0,03 & 17 & 0,01 & 52 & 0,02 \\
\hline 13300 & Construction sites & 1880 & 1,72 & 1570 & 1,08 & 3450 & 1,34 \\
\hline 13400 & Land without current use & 135 & 0,12 & 100 & 0,07 & 234 & 0,09 \\
\hline 14100 & Green urban areas & 6821 & 6,26 & 593 & 0,41 & 7414 & 2,89 \\
\hline 14200 & Sports and leisure facilities & 941 & 0,86 & 78 & 0,05 & 1020 & 0,40 \\
\hline 21000 & Arable land (annual crops) & 265 & 0,24 & 29974 & 20,71 & 31918 & 12,43 \\
\hline 22000 & Permanent crops & 29 & 0,03 & 1393 & 0,96 & 1422 & 0,55 \\
\hline 23000 & Pastures & 0 & 0 & 321 & 0,22 & 321 & 0,13 \\
\hline 25000 & Orchards & 8 & 0,01 & 0 & 0 & 8 & 0 \\
\hline 31000 & Forest & 15125 & 13,87 & 70921 & 49,00 & 86149 & 33,55 \\
\hline 32000 & Herbaceous vegetation associations & 648 & 0,59 & 1249 & 0,86 & 2312 & 0,90 \\
\hline 33000 & $\begin{array}{l}\text { Open spaces with little or no } \\
\text { vegetation }\end{array}$ & 2491 & 2,28 & 2508 & 1,73 & 5112 & 1,99 \\
\hline 40000 & Wetlands & 414 & 0,38 & 420 & 0,29 & 834 & 0,32 \\
\hline 50000 & Water & 3412 & 3,13 & 1058 & 0,73 & 4543 & 1,77 \\
\hline & Total & & 100 & & 100 & 256752 & 100 \\
\hline
\end{tabular}

22 The urban GI occupies 55\% of the city's territory and forests (31000) that make up 33\% of the total area are the most important element. Usually, natural forest in Moscow are 
part of specially designed nature protected areas (PA). The most numerous PA in Moscow are natural and historical parks (10 in total) (the largest PA is the Losiny Ostrov National Park). Both categories correspond to the IUCN Category II.

Protected areas form a special group in GI because of predominately environment protection functions (unlike other territories of the natural complex) and a special protection regime (unlike other green areas). In City Plans, the protected areas are marked as territories with restrictions of city-planning development. Against the existing built-up landscapes, protected areas of Moscow seem to be "islands of the untouched nature". However, for a long time, all of them have been developing under the anthropogenic influence and their current state is the result of both natural landscape-forming processes and the history of cultural landscape formation (nature adaptation for human needs during the long-term development). Therefore, the urban protected areas are not only valuable ecosystems, but also cultural landscapes that provide ecosystems services as land values and cultural identity.

Due to city limits expansion arable lands occupy now the second place by size $(12,43 \%)$. They posses a lot of qualities for climate change adaptation like permeability, saturation and runoff control. Other elements of GI play less important role but the share of green urban spaces $(14,100)$ and water $(50,000)$ in "Old" Moscow is higher than in new parts because of geographical position of old part of city on the valley and banks of River Moscow. Total share of GI elements is almost three times higher in New Moscow (75\%) than in "Old" part (28\%).

Among different types of urban fabrics discontinuous medium density and discontinuous low density ones (soil locked by $30 \%-50 \%$ ) are most common, together occupying more than one half of the built-up area. This ratio is also quite favorable in terms of an urban heat island formation that is one of the most harmful climate change consequences in relation to the human health. But at the same time, areas with continuous and discontinuous dense urban fabric (S.L. level up to $80 \%$ ) that occupy almost 1385 ha (or $0,53 \%$ of the city area) are alarmingly vulnerable to these negative effects.

The introspection of ecosystem services shows that city's parts differ drastically but the level of ecosystem services provision in both part of Moscow is rather high (Table 2).

Table 2. Green Infrastructure and ecosystem services.

\begin{tabular}{|c|c|c|c|}
\hline \multirow[b]{2}{*}{ Ecosystems services * } & \multicolumn{3}{|c|}{ Area, \% } \\
\hline & $\begin{array}{l}\text { "Old" } \\
\text { Moscow }\end{array}$ & $\begin{array}{l}\text { "New" } \\
\text { Moscow }\end{array}$ & $\begin{array}{l}\text { "Big" } \\
\text { Moscow }\end{array}$ \\
\hline Biodiversity/species protection $(31000,32000,33000,40000,50000)$ & 17,13 & 52,61 & 38,53 \\
\hline $\begin{array}{l}\text { Climate change adaptation }(21000,22000,23000,25000,31000,32000 \text {, } \\
33000)\end{array}$ & 17,02 & 73,48 & 49,55 \\
\hline $\begin{array}{l}\text { Climate change mitigation }(14100,14200,21000,22000,23000,25000 \text {, } \\
31000,32000,33000)\end{array}$ & 21,98 & 73,94 & 52,84 \\
\hline $\begin{array}{l}\text { Water management }(21000,22000,23000,25000,31000,32000,33000 \text {, } \\
40000,50000)\end{array}$ & 20,53 & 74,50 & 51,63 \\
\hline Food security $(21000,22000,23000,25000)$ & 0,28 & 21,89 & 13,11 \\
\hline $\begin{array}{l}\text { Recreation, well-being and health }(14100,14200,31000,32000,33000 \text {, } \\
50000)\end{array}$ & 26,99 & 52,78 & 41,55 \\
\hline Land values $(14100,14200,31000)$ & 24,12 & 49,45 & 38,61 \\
\hline Culture and communities $(14100,14200)$ & 7,12 & 0,46 & 3,29 \\
\hline
\end{tabular}

*Codes of items correspond to Table 1. 
Corresponding results might give one an idea that "New Moscow" plays a role of an ecological donor to other city's districts. This statement, however, is true only partially, especially regarding the air basin quality, since it is necessary to consider the prevailing west wind. Other functions of "New Moscow's" green elements are either transitional (for example, runoff regulation) or local (like reducing air temperature background during heat waves). As a result, districts with protected green zones or huge areas of urban forests are in a noticeably more advantageous situation since these green massifs perform "cool island" effect. The Eastern District of "Old Moscow", for instance, is one of them as it shares the biggest part in the total climate change adaptation area.

\section{Urbanization and ecosystem services}

As a city sprawls, surrounding areas are gradually sealed and built-up (Table 3). In 1991 urban built-up areas occupied most of "Old Moscow" territory (43,8\%), and during the post-soviet period their share was only growing, reaching almost $62 \%$ by 2014 . It is also worth mentioning that this kind of expansion was more intense in the period between 1991 and 2000 than during 2001-2014. As to "New Moscow", the share of built-up area has increased only by $4,8 \%$ from $0,6 \%$ in 1991 , while the maximum growth rate here took place between 2001 and 2014.

Table 3. Transformation of main urban expansion types in 1991-2014.

\begin{tabular}{|c|l|l|c|c|c|c|c|c|c|c|c|}
\hline & & \multicolumn{2}{|c|}{ Area, \% } \\
\hline & $\begin{array}{l}\text { Item by Atlas of Urban } \\
\text { Expansion }\end{array}$ & \multicolumn{2}{|c|}{ Urban Atlas Code } & \multicolumn{3}{|c|}{ "Big" Moscow } & \multicolumn{3}{|c|}{ "Old" Moscow } & \multicolumn{2}{c|}{ "New" Moscow } \\
\hline N & & & 1991 & 2001 & 2014 & 1991 & 2001 & 2014 & 1991 & 2001 & 2014 \\
\hline 1 & Urban built-up & $11100-11220,12210,12230,12400$ & 18,9 & 24,9 & 29,0 & 43,8 & 56,2 & 61,6 & 0,6 & 1,8 & 4,8 \\
\hline 2 & Suburban built-up & 11230,12220 & 4,3 & 4,4 & 5,3 & 7,6 & 5,2 & 4,4 & 1,9 & 3,9 & 6,1 \\
\hline 3 & Rural built-up & 11240 & 2,5 & 2,8 & 2,5 & 1,4 & 0,9 & 0,6 & 3,3 & 4,2 & 3,9 \\
\hline 4 & Fringe open space & 13100,14200 & 11,5 & 11,5 & 13,7 & 23,2 & 18,7 & 17,7 & 3,0 & 6,4 & 10,9 \\
\hline 5 & Captured open space & 13400,14100 & 0,6 & 0,8 & 1,2 & 1,3 & 1,4 & 2,1 & 0,1 & 0,3 & 0,6 \\
\hline 6 & Rural open space & $21000-25000,31000-33000,40000$ & 60,9 & 54,4 & 47,2 & 20,1 & 15,2 & 11,6 & 90,7 & 83,1 & 73,5 \\
\hline 7 & Water & 50000 & 1,4 & 1,2 & 1,0 & 2,6 & 2,4 & 2,0 & 0,4 & 0,4 & 0,3 \\
\hline
\end{tabular}

Calculation made by data of Atlas of Urban Expansion, http://www.atlasofurbanexpansion.org/cities/ view/Moscow 
Table 4. Main ecosystem services transformations in 2001-2014.

\begin{tabular}{|c|c|c|c|c|c|}
\hline & \multirow[t]{2}{*}{ Type of change } & \multicolumn{3}{|c|}{ Change of area, $\%$} & \multirow[t]{2}{*}{ Ecosystems services transformation } \\
\hline & & $\begin{array}{l}\text { "Big" } \\
\text { Moscow }\end{array}$ & $\begin{array}{l}\text { "Old" } \\
\text { Moscow }\end{array}$ & $\begin{array}{l}\text { "New" } \\
\text { Moscow }\end{array}$ & \\
\hline 1 & Rural open space - Fringe open space & 4,05 & 1,74 & 5,85 & All ecosystem services decrease \\
\hline 2 & Rural open space - Rural built-up & 0,77 & 0,08 & 1,29 & All ecosystem services decrease \\
\hline 3 & $\begin{array}{l}\text { Rural open space - Captured open } \\
\text { space }\end{array}$ & 0,64 & 0,9 & 0,46 & Fragmentation of urban $\mathrm{Gl}$ \\
\hline 4 & Rural open space - Urban built-up & 0,47 & 0,51 & 0,45 & All ecosystem services decrease \\
\hline 5 & Fringe open space - Urban built-up & 1,62 & 2,69 & 0,83 & Increasing urban density \\
\hline 6 & Fringe open space - Suburban built-up & 0,51 & 0,29 & 0,69 & Increasing urban density \\
\hline 7 & Rural built-up - Suburban built-up & 1,03 & 0,51 & 1,45 & No change \\
\hline \multirow[t]{2}{*}{8} & Suburban built-up - Urban built-up & 1,66 & 1,93 & 1,49 & No change \\
\hline & Total & 10,75 & 8,65 & 12,51 & \\
\hline
\end{tabular}

Calculation made, basing on GIS-modeling

Different processes are revealed for types of suburban built-up and fringe open space for "Old" and "New" Moscow. The shares of these types within "New Moscow" have expanded in comparison to the decrease of these categories in "Old Moscow" that proves the process of urban extension in adjoined parts of city and, on the contrary, development intensification in old part.

At the same time, the share of captured open spaces (or spaces, isolated by built-up areas from other parts of green network) has doubled both in "Old Moscow" and in "Big Moscow". Urban sprawl is also intensely consuming rural open spaces. Their area has dropped from 60,9 per cent in 1991 to 47,2 per cent in 2014, but the decreasing rate is especially high within "New Moscow" limits. This category shrank here from 90,7 per cent to 73,5 per cent. As to "Old Moscow", rural open spaces that used to cover 20,1 per cent there have diminished by a factor of two. Water areas are also shrinking, probably due to the draining and the development of former peatbogs, ponds filling, etc.

Eight types of changes of urban tissue may have three main consequences for ecosystem services (Table 4). As we have already mentioned, all processes related with decreasing of rural open space suggest the reduction of ecosystem services. The rate of such processes is rather high in "New Moscow" - in 2000-2014 it was more than 8 per cent; in old parts of the city it is 3,2 per cent.

At the same time, built-up areas of "Old Moscow" have been mainly expanding at the expense of its inner captured open spaces within territories of low density urban fabric and former industrial zones. As a result, they have increased by 4,6 per cent. These processes are either not characterized by GI functions' transformation or, on the contrary, make urban fabric more compact, a fact that can be interpreted as positive. Moreover, this urban sprawl for "Big Moscow" is three times more rapid (sum of types of change 1-4) than a process of inner compressing (types 5, 6). Compactness of built-up areas also took place that is presented by conversion of rural and suburban areas. In 
2000, land use types in both parts of Moscow were changed significantly, while the rate of conversion in "New Moscow" was higher than in Old part.

\section{Discussion}

supporting ES. While new artificial GI elements like small parks and street trees emerge in densely built-up parts, the city continues to expand at urban forests' expense. Thus, green area, capable of supporting and regulating ES, is gradually replaced by GI elements that provide only cultural ES. This imbalance of ES proves that quantitative assessment of GI is not enough to draw conclusions about its efficiency. In order to conclude whether GI really aids the city in sustainable development, its qualitative features should be brought to attention. A number of studies (Yablokov, 2018; Bobrov, 2011) on urban GI are dedicated to its area assessment. Few, however, take into consideration the difference of GI elements' value and ES provision. typically eclipses consideration of ecosystems contribution to quality of life (Díaz et al., 2006; Grêt-Regamey et al., 2013; MEA, 2005). All these problems are quite common for Moscow where rates of loss of GI elements are rather high.

The expansion of Moscow urban area does not affect provisioning services as much as in other case studies, mentioned by Eigenbrod (2011), Xie (2018) and Zhang (2017). That is explained by a relatively insignificant share of agricultural lands in Moscow's landuse structure. Moreover, they are characterized by high biodiversity of soil invertebrates, accumulate and deposit carbon dioxide - a crucial factor to decrease greenhouse gases emissions (Vasenev et al., 2018). ecosystem services were usually assessed for specific parks and urban forests rather than the whole city's area. The comparison of (Angel et al., 2016) data and our data of Figure 2 showed that the majority of GI corresponds to "rural open space". Only two elements - green urban areas and sport and leisure facilities are in the types of "fringe open space" and "captured open space". But for "Old Moscow" the share of calculated GI is more than twice greater than share of rural open space ( 28 and 11,5 per cent respectively) and the rest part of GI is represented by fringe open space, e.g. - fragmented green areas. only for verification, but to define key ecosystem services for a territory as well. Atlas of Urban Expansion, frequently used in other cities' investigations, is a rare source of information in Russian studies. By incorporating its data into our research we managed to consider the necessity of ecosystem services for different districts, depending on their compactness. 


\section{Conclusions}

Today, development of GI in Moscow mostly depends on two key factors: 1) the government target to provide more accommodation by building-up more city's area; 2) spatial planning, aimed to improve urban environment by creating new green space.

For a city as big and fast-growing as Moscow, GI should not only be carefully planned, but also protected and maintained. Large green elements that remain from the past Master Plans are to be seen as starting points for the further development of GI rather than more area for construction.

2 The Moscow case study approved that processes of ecosystem services reduction is typical for Moscow as for other world megacities but the development of housing market in Post-Soviet time among other consequences led to increasing of urban expansion to open areas that are not protected by special rules and especially for "New Moscow" land. If this process will increase the most considerable area loss is expected in the category of urban forests and parks, while the least significant decrease will probably take place in areas occupied by sports and leisure facilities.

The extension of city limits in 2011 led to including into city area not only forests but also agricultural lands that converted drastically the modern Moscow GI. After the new territories have been joined to "Old Moscow", the situation with green space provision per capita has notably improved. Statistically forests have almost balanced out the urban built-up area.

These indicators, however, do not demonstrate the whole picture, because their calculations include huge areas of protected green zones on the periphery of the city, thus making the results look positive. Meanwhile, however, central districts barely have enough green space for their inhabitants. The comparison of remote sensing data with digital maps revealed that the half of the GI area of Old Moscow is presented by fringe open space and is under threat of future fragmentation.

5 The rural open space (including forests and agricultural lands) with its highest ecological potential turned out to be the most wanted area -an "ideal" resource for urban expansion in New Moscow. But this trend should be considered as most adverse because of potential decreasing of climate adaptation capacity and storm water runoff regulation. Extensive character of urbanization is more typical for Moscow than densification of built-up areas.

46 The present-day situation within the urban PAs is characterized by the expansion of recreational services demand and offer, presence of another landowners, reduction of the number of employees, etc. Unfortunately, the majority of urban forests in "New" Moscow do not have protective status and are vulnerable to urban expansion. 


\section{BIBLIOGRAPHY}

AKBARI H. (2002), "Shade trees reduce building energy use and $\mathrm{CO} 2$ emissions from power plants", Environmental Pollution, 116, pp. 119-126.

ANDRE K., ZUVELA-ALOISE M., LETTMAYER G., SCHWAIGER H.P., KALTENEGGER I., BIRD D.N. \& WOESS-GALLASCH S. (2017), "Modeling reduction of the Urban Heat Island effect to counter-act the effects of climate change in densely built-up areas", EGU General Assembly Conference Abstracts, 19 , p. 15727.

ANGEL S., BLEI A.M., PARENT J., LAMSON-HALL P., SÁNCHEZ N.G., CIVCO D.L., LEI R.Q. \& THOM K. (2016), Atlas of Urban Expansion: Areas and Densities, New York, 500 p., http:// www.atlasofurbanexpansion.org/data.

ATIF S.B. (2018), "Identification of key-trends and evaluation of contemporary research regarding urban ecosystem services: a path towards socio-ecological sustainability of urban areas", Applied Ecology and Environmental Research, 16, 3, pp. 3545-3581.

BARANOV N. V. (1969), Soviet urban planning, Moscow, Stroiizdat.

BARÓ F., CHAPARRO L., GÓMEZ-BAGGETHUN E., LANGEMEYER J., NOWAK D.J. \& TERRADAS J. (2014), "Contribution of ecosystem services to air quality and climate change mitigation policies: the case of urban forests in Barcelona, Spain", Ambio, 43, 4, pp. 466-479.

BENAYAS J.M.R., NEWTON A.C., DIAZ A. \& BULLOCK J.M. (2009), "Enhancement of biodiversity and ecosystem services by ecological restoration: A meta-analysis", Science, 325, pp. 1121-1124.

BOBROV E.A. (2011), "Social-ecological problems of large cities and way of their solution", Estestvennie Nauki of Belgorod State University, 15, 110, pp. 109-209.

CARVALHO R.M., SZLAFSZTEIN C.F. (2019), “Urban vegetation loss and ecosystem services: the influence on climate regulation and noise and air pollution", Environmental Pollution, 245, pp. 844-852.

COSTANZA R. (1997), "The value of the world's ecosystem services and natural capital," Nature, 387, 6630, p. 253.

DALLY G.C. (1997), "Power M. Nature's services: Societal dependence on natural ecosystems", Nature, 388, 6642, p. 529.

DE GROOT R.S., WILSON M.A., BOUMANS R.M.J. (2002), “A typology for the classification, description and valuation of ecosystem functions, goods and services", Ecological economics, 41, 3, pp. 393-408.

DÍAZ S., FARGIONE J., CHAPIN F.S. \& TILMAN D. (2006), "Biodiversity loss threatens human wellbeing", PLOS Biology, 4, 8, p. 277.

EIGENBROD F., BELL V.A., DAVIES H.N., ARMSWORTH P.R. \& GASTON K.J. (2011), “The impact of projected increases in urbanization on ecosystem services", Proceedings of the Royal Society B: Biological Sciences", 278, pp. 3291-3208.

EUROPEAN COMMISSION (2013), Green infrastructure (GI) - Enhancing Europe's Natural Capital, http://eur-lex.europa.eu/resource.html?uri=cellar:d41348f2-01d5-4abe-b817-4c73e6f1b2df. 0014.03/DOC_1\& format=PDF. 
FRÉLICHOVÁ J., FANTA J. (2015), “Service availability in view of long-term land-use changes: A regional case study in the Czech Republic", Ecosystem Health and Sustainability, 1, pp. 1-15.

EEA (2011), Green infrastructure and territorial cohesion: The concept of green infrastructure and its integration into policies using monitoring systems, Technical report, 18, 138 p., https:// www.eea.europa.eu/publications/green-infrastructure-and-territorial-cohesion.

GRÊT-REGAMEY A., CELIO E., KLEIN T.M. \& HAYEK U.W. (2013), “Understanding ecosystem services trade-offs with interactive procedural modeling for sustainable urban planning”, Landscape and Urban Planning, 109, 1, pp. 107-116.

GRUNEWALD K., XIE G. \& WÜSTEMANN H. (2018), “The multiple benefits of urban green ecosystem services assessment", Towards Green Cities, pp. 43-104.

HAASE D., LARONDELLE N., ANDERSSON E., ARTMANN M., BORGSTROM S. et al. (2014), “A Quantitative Review of Urban Ecosystem Service Assessments: Concepts, Models, and Implementation", Ambio, 43, 4, pp. 413-433.

IGNATIEVA M., MELNICHUK I. \& BASHKIROV A. (2013), “St. Petersburg: Towards Integrated and Sustainable Green Infrastructure”, The nature of cities, 1, pp. 56-59.

INKILÄINEN E.N.M. (2013), “The role of the residential urban forest in regulating throughfall: A case study in Raleigh, North Carolina, USA", Landscape and urban planning, 119, pp. 91-103.

IRWIN E.G., BOCKSTAEL N.E. (2007), “The evolution of urban sprawl: Evidence of spatial heterogeneity and increasing land fragmentation", Proceedings of the National Academy of Sciences, 104, 52, pp. 20672-20677.

KOLBOWSKY E. YU, KLIMANOVA O.A. (2013), "Protected areas in the system of spatial planning and functional zoning in Moscow”, Issues of Regional Ecology, 2, pp. 37-45 (in Russian).

KOLBOWSKY E.YU., KLIMANOVA O.A., ARSHINOVA M.A. \& MARGOLINA I.L., (2015), “Landscape Management Within the Moscow City Protected Areas", Landscape analysis and planning: Geographical Perspectives, pp. 257-269.

LARONDELLE N., HAASE D. (2013), “Urban ecosystem services assessment along a rural-urban gradient: A cross-analysis of European cities”, Ecological Indicators, 29, pp. 179-190.

MAHROVA A., NEFEDOVA T. \& TREIVISH A. (2012), "Moscow Agglomeration and New Moscow", Pro et Contra, 6, pp.19-32 (in Russian).

MILLENNIUM ECOSYSTEM ASSESSMENT (2005), Ecosystems and human well-being: synthesis, Washington, DC., Island Press.

UNITED NATIONS (2014), World Urbanization Prospects: The 2014 Revision, Highlights, Department of Economic and Social Affairs.

NOWAK D.J., GREENFIELD E.J., HOEHN R.E. \& LAPOINT E. (2013), “Carbon storage and sequestration by trees in urban and community areas of the United States", Environmental Pollution, 178, pp. 229-236.

SAWKA M., MILLWARD A.A., McKAY J. \& SARKOVICH M. (2013), “Growing summer energy conservation through residential tree planting”, Landscape Urban Planning, 113, pp. 1-9.

SING L., RAY D. \& WATTS K. (2015), “Ecosystem services and forest management”, Research NoteForestry Commission, 20.

TEEB (2011), The Economics of Ecosystems and Biodiversity (TEEB) in National and International Policy Making, London, Earthscan. 
URBAN ATLAS MAPPING GUIDE (2011), European Union, 30 p., https://www.eea.europa.eu/dataand-maps/data/urban-atlas/mapping-guide/urban_atlas_2006_mapping_guide_v2_final.pdf.

VASENEV V.I., STOORVOGEL J.J., LEEMANS R., VALENTINI R. \& HAJIAGHAYEVA R.A. (2018),

"Projection of urban expansion and related changes in soil carbon stocks in the Moscow Region", Journal of Cleaner Production, 170, pp. 902-914.

VLADIMIROV V.V. (1980), "Relevance of geoecological programming prerequisite in the regional planning”, Problems of Geography, 113, pp. 109-117.

VLADIMIROV V.V. (1982), Settlement and environment, Moscow, Stroiizdat.

VORONCOV A.R., KUZMIN A.V. \& TKACHENKO L.Y. (2016), "The coordinated development of Moscow and Moscow City: Old Issues and New Challenges", Gradostroitelstvo, 4, pp. 76-81.

XIE W., HUANG Q., HE C. \& ZHAO X. (2018), "Projecting the impacts of urban expansion on simultaneous losses of ecosystem services: A case study in Beijing, China”, Ecological Indicators, 84, pp. 183-193.

YABLOKOV V.M. (2018), "GIS analysis of green network structure and dynamics in Moscow", Vestnic of Moscow State University, 5, 1, pp. 42-48.

ZHANG D., HUANG Q., HE C. \& WU J. (2017), "Impacts of urban expansion on ecosystem services in the Beijing-Tianjin-Hebei urban agglomeration, China: A scenario analysis based on the shared socioeconomic pathways", Resources, Conservation and Recycling, 125, pp. 115-130.

\section{NOTES}

1. The terms "green infrastructure" or "green areas" have been introduces to Russian paradigm of urban engineering quite recently. Another collocation, "vegetation planting", is much more common. GOST (interstate standard) 28329-89 defines it as a complex of trees, scrubs and grass vegetation in the certain area. However, terms like "ecological network" or "eco-natural network") are more typical for spatial urban planning. When analyzing urbanization progresses in Moscow, we use "green infrastructure" to get a fuller picture of urban expansion consequences and mainly of the transforming ecosystem services of open lands.

2. http://www.atlasofurbanexpansion.org/data.

\section{ABSTRACTS}

Green infrastructure (GI) and ecosystem services (ES) improve the quality of urban life and aid city's sustainable development. During the Soviet period, GI was an important part of spatial planning. Today, many post-Soviet cities face the problem of its deterioration due to the rapid economic growth and subsequent urban sprawl. Moscow is an exceptional case of a European city that both inherits features of central planning and integrates modern methods of greening. This paper aims to define the role of urban expansion in GI and ES transformation in Moscow during the last 25 years. Our method is based on combining spatial data on land-use from Open Street Map and Atlas of Urban Expansion, and reclassified Landsat images. 
The research revealed that the most important for ES provision land categories have gradually shrunk, especially in old Moscow, where the share of built-up area has increased by $18 \%$. Considering the results, we stress that recent GI development mostly concerns small GI elements that do not provide regulating or supporting ES, while large GI massifs continue to deteriorate, thus resulting in a misbalance of urban ES provision.

Les infrastructures vertes et les services écosystémiques améliorent la qualité de vie dans les villes et contribuent à leur développement durable. Sous le régime soviétique, les infrastructures vertes formaient une part considérable du développement territorial. Aujourd'hui, la plupart des villes post-soviétiques sont confrontées à leur détérioration en raison du développement économique fulgurant et de l'expansion urbaine qui s'ensuit. La ville de Moscou représente un cas particulier en Europe dans la mesure où elle doit combiner les caractéristiques d'un aménagement centralisé et la nécessité d'intégrer les méthodes modernes d'écologisation. Cet article tente de définir le rôle de l'expansion urbaine dans la transformation des infrastructures vertes et des services écosystémiques à Moscou au cours de ces 25 dernières années. Notre méthode se base sur la combinaison des données spatiales relatives à l'occupation du territoire à partir d'Open Street Map, de l'Atlas de l'expansion urbaine, ainsi que d'images Landsat reclassifiées.

Notre recherche a révélé que l'utilisation des sols en faveur d'écosystèmes verts s'est peu à peu restreinte, en particulier dans l'ancien Moscou où la part des zones bâties s'est accrue de $18 \%$.Au vu de ces résultats, nous soulignons le fait que le développement d'infrastructures vertes récent concerne principalement les petites entités où il n'existe ni régulation ni soutien aux services écosystémiques, alors que beaucoup d'infrastructures vertes continuent de se détériorer, ce qui crée un déséquilibre de la fourniture de services économiques urbains.

\section{INDEX}

Keywords: urban sprawl, urban expansion, land-use transformation, urban green network, spatial analysis, urban environment, spatial planning, urban protected areas, Moscow

Mots-clés: expansion urbaine, modification de l'occupation des sols, réseau d'espaces verts, analyse spatiale, environnement urbain, aménagement du territoire, zones urbaines protégées, Moscou

\section{AUTHORS}

\section{OXANA KLIMANOVA}

Lomonosov Moscow State University, Department of Geography, Associate Professor, Corresponding author, oxkl@yandex.ru

\section{EUGENY KOLBOWSKY}

Lomonosov Moscow State University, Department of Geography, Leading Researcher, kolbowsky@mail.ru

\section{OLGA ILLARIONOVA}

Lomonosov Moscow State University, Department of Geography, MSc. Student, heatherpaw95@gmail.com 